\title{
Hospital Medical Record Indicator
}

National Cancer Institute

\section{Source}

National Cancer Institute. Hospital Medical Record Indicator. NCI Thesaurus. Code C135386.

An indication as to whether medical records were obtained from the hospital. 